\title{
Turkey and Germany in the Balkans: Competing with Each Other?
}

\author{
ELIF NUROĞLU* and HÜSEYIN H. NUROĞLU*
}

ABSTRACT This paper aims to see whether there is a commercial and financial rivalry between Turkey and Germany in the Balkans by examining the export volumes, exported items, and foreign direct investments of these two countries to five Balkan countries. Our findings show that the commercial competition between Turkey and Germany in the Balkans is not serious. However, as the export growth of Turkey in the region continues to increase as it has done in the last two decades, Turkey has the potential to be a serious competitor to Germany in electrical goods and appliances, motor vehicles parts and components, power generating machinery and vehicles, metal articles, specific and general industrial machines, and plastics.

\section{Introduction}

$t$ is claimed in academic circles and in the media that there is a conflict of interest in the Balkans between Turkey and the EU in general, but Germany in particular. ${ }^{1}$ Many countries such as Russia, China, India, the EU, and the U.S. vie to expand their economic, cultural, and political influence in the Balkans. Germany has many advantages in this competition as a main trade partner and creditor of the Balkan countries. ${ }^{2}$

The Balkans is an important element in the foreign policy of Turkey, which has deep historical and cultural ties with the region. One of the basic principles of this policy has been designated as maximum economic integration. Western countries, on the other hand, aim to guarantee their energy supply and achieve their strategic goals under the stance of bringing stability to the Balkans. ${ }^{3}$

This paper aims to examine the extent of commercial and financial rivalry between Turkey and Germany in the Balkans. We examine export volumes, exported items, and foreign direct investments (FDIs) of Germany and Tur- 



\section{Although Turkey's interest and activism in the Balkans is not new and cannot solely be attributed to the AK Party government, the inclusion of an economic aspect in Turkish foreign policy is something new}

components, power generating machinery and vehicles, metal articles, specific and general industrial machines, and plastics. It is also worth mentioning that Germany's export size as of 2017 is 9.2 times bigger than that of Turkey's. Therefore, when analyzing Turkey and Germany's exports to the Balkans, the commercial supremacy of Germany should always be kept in mind.

\section{Increasing Presence of Turkey in the Balkans}

As a result of changes in regional and global conditions, and the increased self-confidence of Turkey in the last decades, Ankara started pursuing a soft power policy in the Balkans. ${ }^{4}$ The development of a 'Balkan Vision for the Future, which was introduced by Ahmet Davutoğlu, then the Minister of Foreign Affairs, is an important step. Balkan countries as transition economies need lots of investment, a need which was also realized by Turkish authorities who want to integrate more with the economies in the region around Turkey. The multi-dimensional foreign policy followed by the ruling AK Party government after 2002 shows itself as increased economic and commercial relations with neighboring countries. Although Turkey's interest and activism in the Balkans is not new and cannot solely be attributed to the AK Party government, the inclusion of an economic aspect in Turkish foreign policy is something new. As a result of Turkey's economic achievement after 2002, it has started to prioritize the role of enhanced economic relations and interdependence with all neighbors including the Balkans. ${ }^{5}$ The Turkish business world was also designated as the primary driver of Turkish foreign policy, ${ }^{6}$ and Turkey has been transformed into a trading state that promotes trade and investment. ${ }^{7}$

Turkey's activism in the Balkans was also driven by external factors such as structural shifts related to the spread of democracy, Europeanization, and globalization; rather than by ideology or Ottoman nostalgia. The European Union's expansion towards the Balkans transformed Turkey's approach from power politics to a multidimensional policy based on trade, foreign investments, and application of soft power. To understand Turkey's increased involvement in the Balkans, there is no need to return to the Ottoman times but it is enough to analyze the 2000s better. Stabilization in the Balkans and the EU integration goals of the countries in the region made the Balkans suitable for investment not 
The Western Balkan countries' desire to be accepted in the EU has been put on hold because of the EU's internal problems like Brexit, and that situation has exposed the Balkans to additional economic and political influence from Turkey, China, and Russia only for Turkey but also for many international actors. The developments after the Customs Union with the EU in 1996 and the signed Free Trade Agreements with the Balkan countries paved the way to more integration. ${ }^{8}$

A high level of enthusiasm from Turkey to improve cultural and economic relations with the Balkans coincides with the slowdown of the ongoing EU accession process of

the Western Balkan countries that increased the chance of Turkey to revive demographic and cultural linkages with the countries in the region. ${ }^{9}$ It has even motivated Serbian politicians, who have many reservations about Turkey, to seek for Turkish investors in İstanbul. ${ }^{10}$ This situation led German scholars to warn the EU leaders about losing their strength in the Balkans and giving rein to Russia, Turkey, China, and other states which have interests in the region. ${ }^{11}$ The Western Balkan countries' desire to be accepted in the EU has been put on hold because of the EU's internal problems like Brexit, and that situation has exposed the Balkans to additional economic and political influence from Turkey, China, and Russia. ${ }^{12}$ Although Turkey's increasing investments and concomitant soft power have disturbed France's Emmanuel Macron who told the European Parliament before the EU Summit in 2018, that he did not want a Balkans that turns toward Turkey or Russia, the EU does not know how to tackle Turkey's increasing influence in the region. ${ }^{13}$ Hatipoğlu compares Turkey's successful mediation attempt in the Balkans, which resulted in the İstanbul Declaration, with the failure of the Prud/Butmir process, and suggests that Turkey's historical ties can add richness to bureaucratized European foreign policy. ${ }^{14}$

Turkey traditionally formulated its foreign policy based on geopolitical and security calculations. The Balkans has always been a major security concern for the Republic of Turkey and there is indeed continuity in Turkey's formulation of its relations with the region. Since Davutoğlu came to power, Turkey did approach the region with a better structured vision, greater pro-activeness, and significant exercise of its soft power capabilities. However, trade relations and investments of Turkey in the region are modest and did not develop in line with strategic interests. ${ }^{15}$

Turkey has signed Free Trade Agreements first with North Macedonia in 1999, and then similar agreements with all countries in the Balkans in the 2000s to remove trade barriers and improve economic cooperation. However, Turkey's 
trade volumes with the Balkans indicate that economic relations do not develop in line with strategic and political goals. When we consider that Turkey makes only seven percent of its foreign direct investments to the region, it is apparent that the Balkans are not among the economically most favored regions for Turkey. In fact, compared to the EU countries, Turkey invests in and trades less with the Balkans. ${ }^{16}$ Most of the Balkan markets are not attractive for Turkish businessmen due to their small size and poor population. ${ }^{17} \mathrm{Nev}-$ ertheless, the observed increase in Turkey's investments since the 2000s, and improvement in trade relations show that Turkey's efforts in the region do give positive outcomes. ${ }^{18}$ This improvement is also observed in the 2017 figures. In the first nine months of 2017, Turkey's foreign trade volume with 11 Balkan countries was approximately $\$ 14$ billion, recording an increase of 17.5 percent compared to the same period of the previous year. ${ }^{19}$

Table 1 shows that exports to the Balkan countries constitute 6.4 percent of Turkey's total exports in 2017, while the Balkans' share is only 2.5 percent in Germany's total exports. Although Turkey's exports are lower in volumes, they constitute a higher share in total. It is seen in Table 1 that in 2017 Turkey's total exports constitute 0.11 percent of Germany's total exports. It is also obvious in the table that both countries could not yet reach pre-crisis levels of exports. This has to do with the close connection and high integration of the Balkan countries with the EU. Since they conduct two thirds of their trade with the EU countries, they were severely hit by the crisis.

Table 1: Total Export Volumes and Exports to the Balkans from Germany and Turkey between 2008 and 2017

\begin{tabular}{|c|c|c|c|c|c|c|}
\hline \multirow[b]{2}{*}{ Year } & \multicolumn{2}{|c|}{$\begin{array}{l}\text { Total Exports } \\
\text { (Million \$) }\end{array}$} & \multicolumn{2}{|c|}{$\begin{array}{l}\text { Exports to the Balkans } \\
\text { (Million \$) }\end{array}$} & \multicolumn{2}{|c|}{$\begin{array}{l}\text { Share of Exports to the } \\
\text { Balkans in Total Exports }\end{array}$} \\
\hline & Germany & Turkey & Germany & Turkey & Germany & Turkey \\
\hline 2008 & $1,450,572$ & 132,027 & 38,383 & 10,858 & $2.6 \%$ & $8.2 \%$ \\
\hline 2009 & $1,121,034$ & 102,143 & 27,699 & 6,826 & $2.5 \%$ & $6.7 \%$ \\
\hline 2010 & $1,261,480$ & 113,883 & 26,639 & 7,157 & $2.1 \%$ & $6.3 \%$ \\
\hline 2011 & $1,477,278$ & 134,907 & 30,072 & 7,747 & $2.0 \%$ & $5.7 \%$ \\
\hline 2012 & $1,404,355$ & 152,462 & 28,216 & 7,192 & $2.0 \%$ & $4.7 \%$ \\
\hline 2013 & $1,444,858$ & 151,803 & 29,574 & 7,810 & $2.0 \%$ & $5.1 \%$ \\
\hline 2014 & $1,492,539$ & 157,610 & 32,766 & 8,678 & $2.2 \%$ & $5.5 \%$ \\
\hline 2015 & $1,326,360$ & 143,883 & 29,962 & 7,821 & $2.3 \%$ & $5.4 \%$ \\
\hline 2016 & $1,332,514$ & 142,530 & 32,558 & 8,645 & $2.4 \%$ & $6.1 \%$ \\
\hline 2017 & $1,444,850$ & 157,000 & 36,324 & 10,063 & $2.5 \%$ & $6.4 \%$ \\
\hline
\end{tabular}

Source: TÜiK and Destatis, 2018. 


\section{Balkans as a Soft Power Application Area}

Turkey has begun to follow an active policy in the Balkans following its economic achievement in the last two decades. As a result of purely economic interest and pursued internal and external policies, Turkey wanted to develop commercial relations with the Balkans and at the same time act as a mediator in the solution of political disputes. ${ }^{20}$ There is a prevailing opinion in some circles that Turkey and Germany compete in the region in practicing soft power, ${ }^{21}$ with some EU members expressing their concerns about the soft power Turkey practices in the Balkans. ${ }^{22}$ Although the West viewed Turkey as a stabilizing force for many years, today the country is seen as a competitor. Therefore, it is suggested that the EU and Germany should monitor the situation closely and be proactive in addressing the challenges regarding the influence of external actors, such as China, Turkey, Russia, and the Gulf states. According to Hänsel and Feyerabend, the EU's reputation is suffering amongst the people of Southeast Europe with a recent study carried out in the Western Balkans showing that 28 percent of those surveyed no longer want to join the EU and only 42 percent think that seeking EU membership is a positive step. The EU has an image and credibility problem in the region. Therefore, Balkan states, governments, and society as a whole are turning towards external actors. $^{23}$

The reasons for Germany and other EU countries' interest in the Balkan markets are relatively low labor costs, increased institutional and political stability, and the expectation that the more advanced countries in Southeast Europe will join the EU soon. ${ }^{24}$ Additionally, geographical proximity, rising education standards, as well as minor cultural differences are other reasons for the growing interest in nearshoring in Eastern European countries. ${ }^{25}$ Furthermore, Germany would like to fight with the reasons of migration, so that there is less migration from these countries into Europe. They also aim to create jobs for Balkan youth, again for the same reason. ${ }^{26}$ The focus of the EU is particularly on stability, promoting democracy, market economy, and good governance. ${ }^{27}$

There are two types of perceptions for Turkey in the Balkans. The first one is the 'rising Turkey' perception while the other one is the fear of 'Neo-Ottomanism' created by the circles disturbed by the presence of Turkey. Turkish investments are appreciated in the areas where the 'rising Turkey' perception is dominant; however, they are regarded as economic invasions of Turkey where the concerns of Neo-Ottomanism are prevalent. These regions prefer to establish economic cooperation with the Western states, especially with Germany, instead of Turkey. ${ }^{28}$ This creates an opportunity for German industries to take advantage of well-educated, multilingual, and low-wage post-socialist labor force in the Balkan countries especially in food, telecommunication, manufacturing, and finance industries. ${ }^{29}$ 
Ankara specifies some strategic sectors such as banking, transportation, and telecommunication in the region and makes purchases or acquires tenders in these sectors. However, Turkey cannot realize all plans mostly due to the lack of resources. It cannot engage in projects in the energy sector due to Russia's plans, and is also too late to enter into the telecommunications field. ${ }^{30}$ Turkey places a priority on Albania, Bosnia, and Herzegovina, and Kosovo due to their high Muslim population, and its trade with these countries increases steadily. However, Turkey's relationship with the region seems to be focused more on cultural and educational programs rather than increasing trade and investment. ${ }^{31}$

The fact that Turkey has been playing an active role in the international arena and in the Balkans has begun to disturb Germany and other Western countries. According to them, Turkey now pays less attention to the interests and wishes of its Western allies compared to previous decades. ${ }^{32}$ Though the rhetoric that Turkey has a secret agenda on the Balkans and it wants to revive the Ottoman Empire is rejected by the Turkish leaders, ${ }^{33}$ it is necessary to take into account any prejudices about Turkey in the region and to fight against these. ${ }^{34}$ Turkish diplomats and scholars persistently declare that their role and presence does not contradict with the EU goals but only complements their efforts in the region. ${ }^{35}$

\section{The Balkans as a Possible Trade Conflict Zone}

\section{Data and Methodology}

In general, 11 countries are listed as Balkan states, these are Albania, Bulgaria, Bosnia and Herzegovina, Croatia, Montenegro, Kosovo, North Macedonia, Romania, Serbia, Slovenia, and Greece. In this study, we include Kosovo, which is one of the two countries to which Turkey's export volumes are higher than Germany, as well as Bulgaria, Greece, Serbia, and Romania. Romania has a big market and it is both Turkey's and Germany's biggest trade partner in the Balkans. When we examine export figures of Germany and Turkey, we see that these five countries account for more than 80 percent of Germany and Turkey's total exports to the Balkans as Table 2 indicates. This sample provides us a representative ground to interpret Germany and Turkey's export tendency in the Balkans. Hence, this paper is going to compare export volumes and the top 10 export items of Turkey and Germany to Bulgaria, Kosovo, Romania, Serbia, 


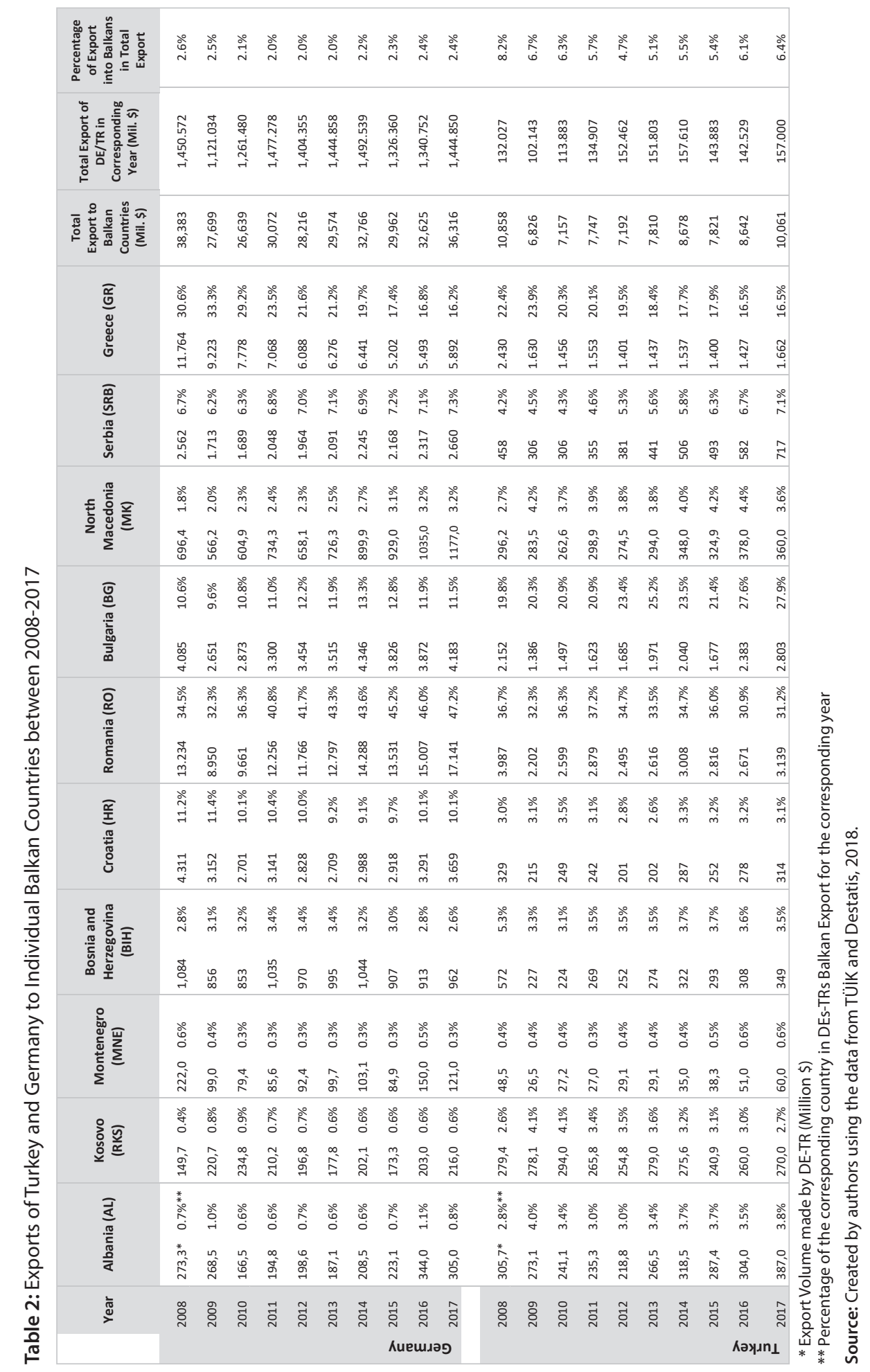


and Greece during the ten-year period covering 2008-2017. Moreover, German and Turkish investments in these five countries are also going to be compared. The data is acquired from the Turkish Statistical Institute (Türkiye İstatistik Kurumu, TÜİK) ${ }^{36}$ and Federal Statistical Institute of Germany (Statistisches Bundesamt, Destatis). ${ }^{37}$

\section{Competition between Turkey and Germany in the Bulgarian market is predicted to increase in the coming years, especially in product groups such as industrial machinery and equipment, electrical goods, motor vehicles, and parts}

\section{Bulgaria}

Bulgaria considers Germany as its most important strategic partner in the European Union. Many German experts who have consulted Bulgaria in the EU accession and integration process are currently active in various ministries in Bulgaria. ${ }^{38}$ Today there are about 5,000 German companies active in the Bulgarian market and 1200 of these are represented by a Bulgarian manager. ${ }^{39}$ The German-Bulgarian Chamber of Commerce (DBIHK) is the chamber of commerce with the largest number of members (500 members) in Bulgaria. The low labor costs in Bulgaria, high number of German-speaking workers, low taxes, EU membership, and Bulgaria's strategic position as a bridge between Asia and Europe plays an important role in the preference of German companies. ${ }^{40}$ In 2016, German investments in Bulgaria amounted to $€ 293.4$ million. ${ }^{41}$

Cultural relations between Germany and Bulgaria are also quite advanced. A Cultural Agreement was signed between the two countries in 1996, and following this, Germany sent German language teachers to Bulgaria. German is the most learned language in Bulgaria after English and Russian, Bulgarian young people are very interested in studying in Germany. One of the largest foreign student groups in Germany is Bulgarian students. ${ }^{42}$ Interestingly, in Bulgaria there is a higher demand for call center workers who speak German, French, or Dutch than those who speak English and they are paid higher salaries. ${ }^{43}$

In Bulgaria, there are 52 Turkish companies employing about 10,000 people with the total amount of investment by these companies being approximately $\$ 2$ billion. These Turkish firms are active in the fields of industry, health, banking and tourism, textile and apparel, home appliances, auto spare parts, transportation, aluminum, food, water bottling, and wood processing. ${ }^{44}$

Figure 1 shows that Germany's exports to Bulgaria are about twice as much as Turkey's. Most exported products from Turkey to Bulgaria are textile products, 
Figure 1: Exports of Germany and Turkey to Bulgaria between 2008-2017 (Million \$)

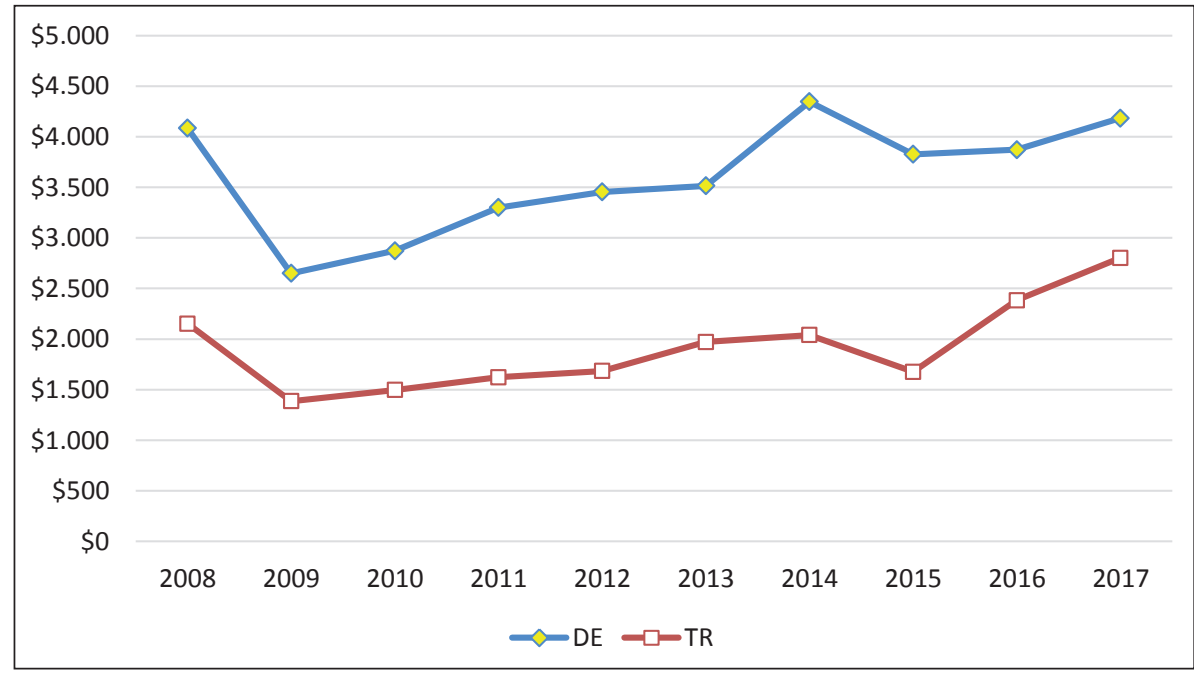

Source: TÜiK and Destatis, 2018.

mining products, motor vehicles, electrical goods, vegetables, and fruits. ${ }^{45}$ The most exported products from Germany to Bulgaria are motor vehicles, industrial machinery and components, industrial machinery/equipment, and electrical goods. ${ }^{46}$

In recent years, exports of motor vehicles from Turkey to Bulgaria have reached quite high numbers, for example, last year, Turkey's exports of motor vehicles increased by 16 percent and electrical goods by 13 percent. ${ }^{47}$ Competition between Turkey and Germany in the Bulgarian market is predicted to increase in the coming years, especially in product groups such as industrial machinery and equipment, electrical goods, motor vehicles, and parts.

\section{Kosovo}

Germany has accepted many refugees from Kosovo before and after the 19981999 war and recognized the country immediately after it declared its independence in February 2008. Many German companies also took part in the reconstruction of Kosovo after the war. ${ }^{48}$

For Germany, the development of Kosovo is very important for the stability of the region. Germany provides technical and financial support for public administration, democratization, civil society, basic education, infrastructure development in water and energy supply, sustainable economic development, and employment promotion in Kosovo. Since 1999, Germany's financial sup- 
port to Kosovo has reached half a billion Euros. This makes Germany the second largest donor after the U.S. ${ }^{49}$ and German is the second most widely spoken foreign language in Kosovo.

Kosovo has a consumption society with very little of its own production. The economy depends mostly on aids from other countries and the remittances of workers from Kosovo who work abroad, especially in Germany and Switzerland. ${ }^{50}$ Workers' income accounts for 10-15 percent of Kosovo's gross domestic product, and foreign aid accounts for one-third of the gross domestic product. ${ }^{51}$

According to the Central Bank of Kosovo, the top five foreign direct investors in Kosovo in 2017 were Switzerland, Turkey, the UK, Albania, and Germany respectively. ${ }^{52}$ The airport construction and operation investment is the highest foreign direct investment, of $€ 40$ million, made by Turkey to Kosovo. The second biggest investment constitutes the energy sector with €26.3 million. In the construction of Pristina International Airport, which is one of the major projects undertaken by Turkish companies, the contractor is Limak-Airports de Lyon Consortium. The airport's new terminal building and its additional facilities, which were an investment of $€ 140$ million, were put into service in $2013 .{ }^{53}$ In the project of Kosovo Electric Power Distribution and Procurement, Limak-Çalık Consortium operates as a contractor. With Enka-Bechtel partnership, the highway construction linking Kosovo to the Adriatic Sea is a huge investment to the amount of $€ 700$ million. ${ }^{54} 586$ of the 4,908 foreign-funded companies in Kosovo belong to Turkish businessmen and the number of active Turkish firms is $325 .{ }^{55}$ Turkey provides scholarships for 120 students from Kosovo each year and these students contribute to the improvement of bilateral relations. ${ }^{56}$

Kosovo is an attractive country for investors from Turkey, with low tax rates of 10 percent and an opportunity to export to all of Europe. In addition, Turkish businessmen have opportunities to invest in areas such as agriculture, construction, infrastructure, and mining, where they can carry on their business without experiencing any language and cultural problems. ${ }^{57}$

Figure 2 shows that Turkey's export volumes to Kosovo are higher than Germany's. Among the products exported from Turkey to Kosovo are clothing articles, textile products, electrical goods, appliances and tools, articles of iron, 
steel, copper, nickel, aluminum, and other common metals, and components of general industrial machinery and devices. The value of exports for industrial machinery and parts alone, increased by 17 percent between 2016 and 2017. On the other hand, Germany exports mostly motor vehicles to Kosovo, followed by plastics in non-primary forms. In contrast to other countries in the Balkans, Germany's exports of milk, dairy products and eggs, tobacco and tobacco products are quite high in Kosovo. The possible competition in the future between Germany and Turkey in the Kosovo market can be in the sectors of electrical goods, general and specific industrial machinery, since both countries have similar export volumes in these product groups. ${ }^{58}$

Figure 2: Exports of Germany and Turkey to Kosovo between 2008-2017 (Million \$)

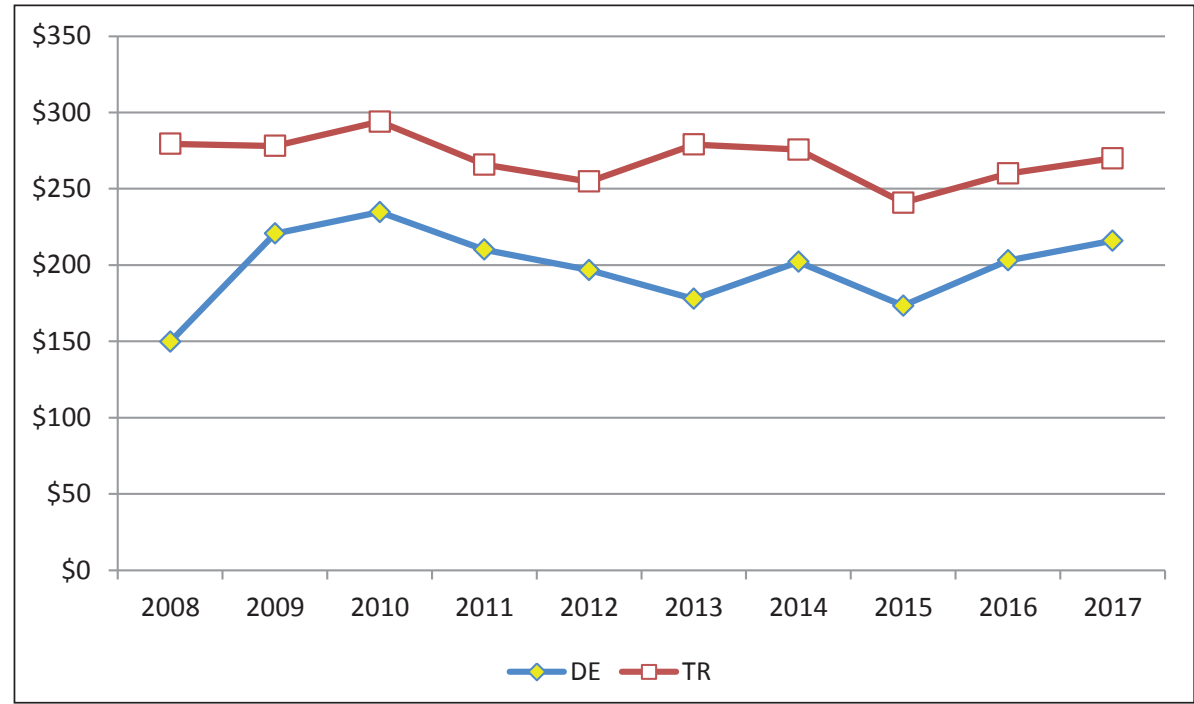

Source: TÜiK and Destatis, 2018.

\section{Romania}

Romania attaches a high importance to foreign trade for economic development and has made many reforms for this purpose. As a full member of the European Union since January 1, 2007, Romania has become more attractive for investment and production. ${ }^{59}$ It is called the 'outsourcing valley' for software development and customer services due to the country's attractiveness for European companies with its multilingual talent pool and cultural proximity to Europe. ${ }^{60}$

In Romania, tax revenues do not reach adequate levels due to a large informal economy, high rural population, and the inability to collect taxes on a regular basis. For this reason, the country cannot generate sufficient funds for edu- 
cation, health, welfare, infrastructure, and security expenditures. Among Eastern European countries, Romania has the second lowest per capita income after Bulgaria, the lowest level of environmental standards, the highest unpaid taxes, and the lowest education spending. Romania makes over 70 percent of its exports to the EU countries, and approximately 82 percent of the banks' assets in Romania are owned by resident banks in the EU countries therefore EU funds are crucial for the Romanian economy, which cannot even generate income with the tax system for its own expenditure. It is expected that the amount of EU funding to Romania will be higher in the coming period than in previous years. ${ }^{61}$

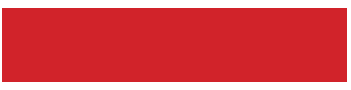
When we compare exports of both countries, there is not any competition in trade in the Romanian market due to the significant German dominance

Turkey-Romania relations were upgraded to a strategic partnership level in December 2011 with the Strategic Partnership Agreement. The Action Plan for the passage of the Strategic Partnership Document was signed in March 2013. Turkish investments in Romania, together with those coming from third countries, totaled $\$ 6.5$ billion. Currently, around 10,000 Turkish firms are active in Romania. Up to now, 90 projects of Turkish contractors have been implemented in Romania, amounting to $\$ 6.2$ billion. ${ }^{62}$ In Romania, there are two Turkish banks, Credit Europe and Garanti Bank. ${ }^{63}$ These two Turkish banks rank the second and third in terms of the most widespread branch network in Romania. ${ }^{64}$

The Romanian market is very important for Germany, as well. In 2018, it was declared that approximately 21,595 German firms were registered in Romania's trade registry, with 8,000 of these companies being active in the market. German investments in the country are mostly made in automobile subsidiary, service sector and major retail chains. There are more than 580 members of the German-Romanian Chamber of Commerce, and members of this chamber employ 300,000 people in total. ${ }^{65}$

There is a German minority of 45,000 people in Romania. This minority is seen as an influential factor in keeping the interest in German language and culture alive. They are also politically very powerful and had one of their members, Klaus Johannis, elected as the president of the country in the 2014 elections. ${ }^{66}$

In Romania, there are many official German institutes as well as NGOs such as Goethe-Institute, German External Relations Institute (DGAP), the Alexander von Humboldt Foundation $(\mathrm{AvH})$, the German Academic Exchange Service (DAAD), and the Center for Overseas Schools Agency (ZfA). In addition to these, Friedrich-Ebert, Konrad-Adenauer, and Hanns-Seidel foundations have 
offices in Bucharest and they shape their work according to Romania's internal and external politics. ${ }^{67}$

Romania attracts the biggest share of exports from Germany and Turkey. In 2017, Germany's export volumes to Romania were approximately $\$ 17.14$ billion, while Turkey's exports to Romania were at the level of $\$ 3.14$ billion. Germany's exports to Romania are approximately 5.5 times higher than Turkey's exports as Figure 3 indicates. Whereas 47.2 percent of Germany's total Balkan exports go to Romania, Romania's share in Turkey's total Balkan exports is 31.2 percent.

Figure 3: Exports of Germany and Turkey to Romania between 2008-2017(Million \$)

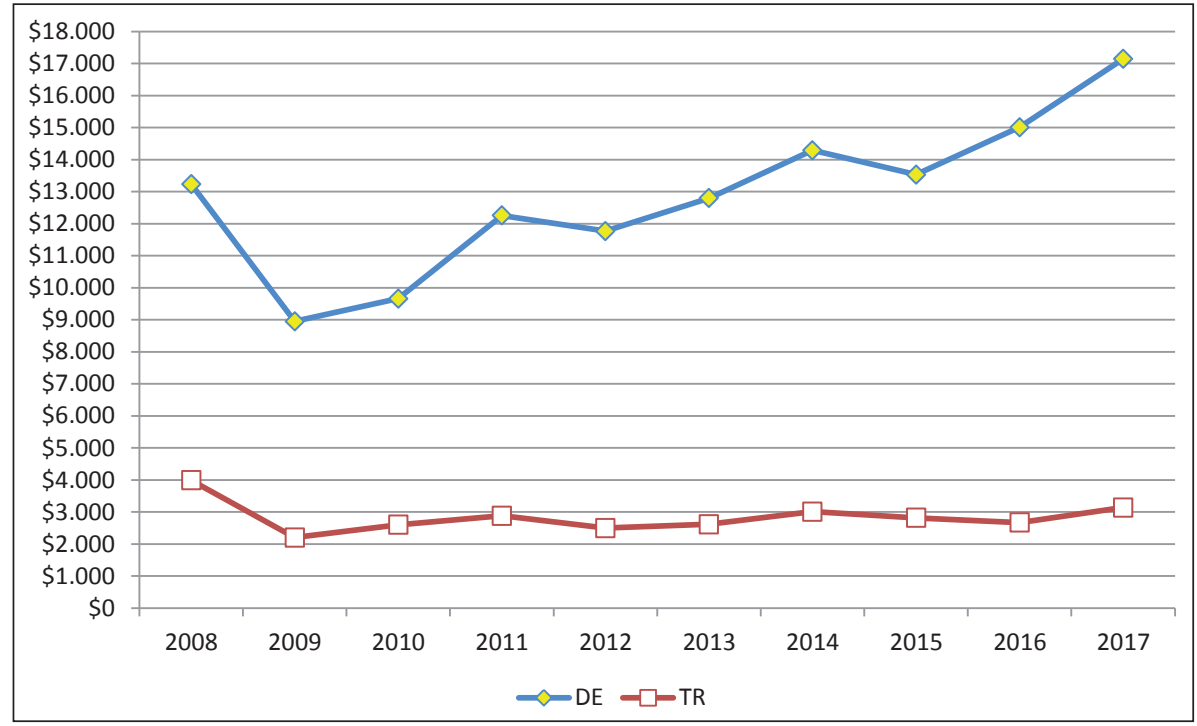

Source: TÜiK and Destatis, 2018.

Germany's export items to Romania show a stable course. The first three product lines exported in the last four years remained the same, and there were only minor changes in the first ten product groups. The products that Germany extensively exports to Romania are electrical goods, land vehicles, general industrial machinery and equipment parts, machinery specialized for particular industries, special transactions and commodities, articles of iron, steel, copper, nickel, aluminum and other common metals, and textile products (yarns, fabrics, floor coverings, ready goods). Unlike other Balkan countries, Germany exports more electrical goods to Romania than motor vehicles. Apart from industrial products, Germany's sales of meat, milk, eggs, coffee, tea, and cocoa are also significant. ${ }^{68}$

Turkey's most exported products to Romania are iron and steel, apparel, textile products, motor vehicles and their parts. These are followed by power 


\section{Wirtschaftsforum Bulgarien mit S.E. Rumen Radev Staatspräsident der Republik Bulgarien}
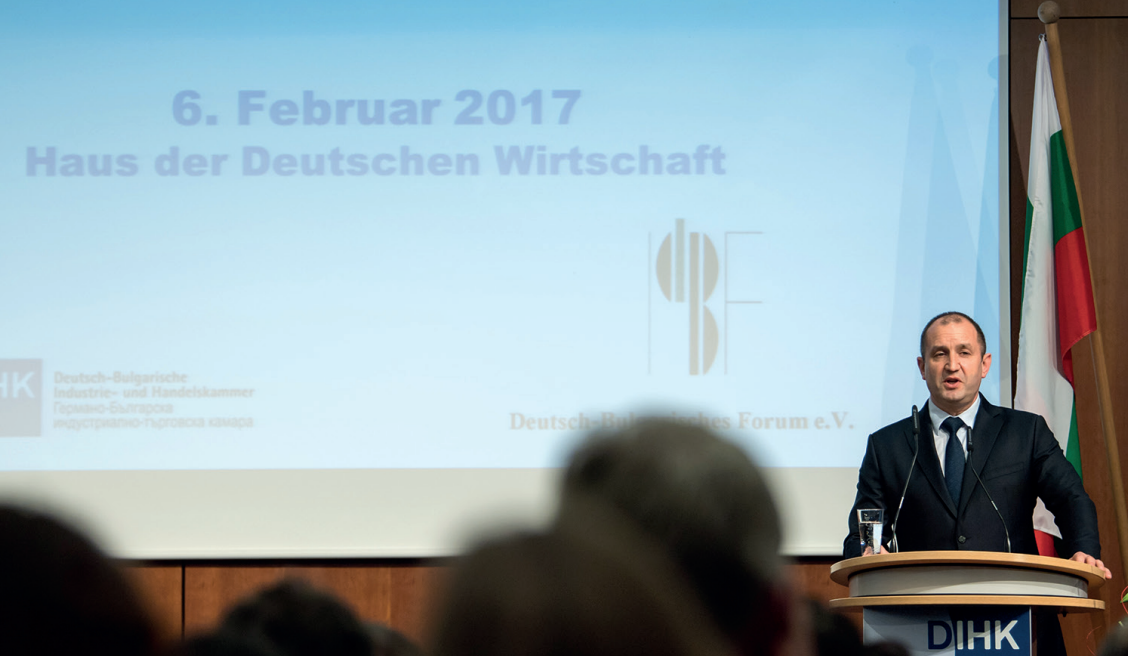
Turkish exporters who are interested in being competitive in Serbian markets should spend more effort on higher technology level products so that Turkey might have an opportunity to compete in the Serbian market with Germany
In recent years, Serbia has gone to legal action in many areas to comply with the EU policies and laws. In this process, an attempt was made to create a favorable environment for foreign investors. Since 2000, the country has attracted over $\$ 25$ billion of foreign direct investment. When we look at the distribution of FDI inflows to Serbia since 2000, it is seen that the share of the EU countries in total investments is around 70 percent. Countries that invest most in Serbia are, in decreasing order with percentages: Italy (13.6), the U.S. (11.9), Austria (11.8), Norway (8.5), Greece (8.3), Germany (7.0), and France (5.0). According to the data of the Central Bank of the Republic of Turkey, Turkey's investments in Serbia in the 20052017 period amounted to $\$ 70$ million, which compared to other countries is relatively low. ${ }^{71}$

Serbia exports most to the Balkan countries and to the EU. In 2017, Germany comes the second in the export figures with a 12.6 percent share, after Italy. Turkey ranks the $18^{\text {th }}$ in Serbian export figures with a 1.8 percent share. In Serbia's imports, Germany ranks the first country with a 12.7 percent share and Turkey ranks the seventh with 3.7 percent. ${ }^{72}$ However, official figures do not fully reflect real trade volumes between Germany and Serbia. Since many German companies have a sister company in Serbia, they conduct business through these companies to buy and sell merchandise to third countries. ${ }^{73}$

Serbia's position is very important for the transportation of Turkish products to the EU markets. Turkish firms investing in Serbia can benefit from duty-free and quota-free exports to all CEFTA countries with a population of about 30 million, and they enjoy great advantages if they export through Serbia to other European countries. ${ }^{74}$

Currently, Turkish firms in the country are mostly engaged in the field of construction. For example, the construction of the U.S. Embassy costing €200 million was carried out by Kolin and Epik Construction, which established a consortium with Framoco from the U.S. Yüksel Construction is building a motorway with the credit of Turkish Eximbank. Apart from these, there are small and medium-size Turkish firms operating in textile, food, construction materials, and carpet sectors. ${ }^{75}$

One of the most important foreign trade partners of Serbia is Germany. The German-Serbian Business Partnership has more than 250 members. ${ }^{76}$ There are 
400 German companies active in Serbia according to 2015 figures. ${ }^{77}$ The main themes of the German-Serbian cooperation are public infrastructure, particularly environment-friendly and efficient energy and water supply, promotion of economic development including support for legal reforms, strengthening of the financial sector and modernization of vocational education, social development and youth work. The projects funded by Germany are mostly carried out by the German Development Bank (KfW), German International Cooperation Organization (GIZ), and International Center for Migration and Development (CIZ). On the other hand, Konrad-Adenauer, Heinrich Böll, Friedrich Ebert, Friedrich Nauman, and Rosa Luxemburg foundations are also active in Serbia. ${ }^{78}$

Serbia ranks the fourth country for Turkey and fifth for Germany in exports. Turkey's exports to Serbia are almost $\$ 826$ million while Germany's exports to Serbia are $\$ 2.806$ million, ${ }^{79}$ therefore Germany's export volumes to Serbia are three times more than Turkey's.

Figure 4: Exports of Germany and Turkey to Serbia between 2008-2017 (Million \$)

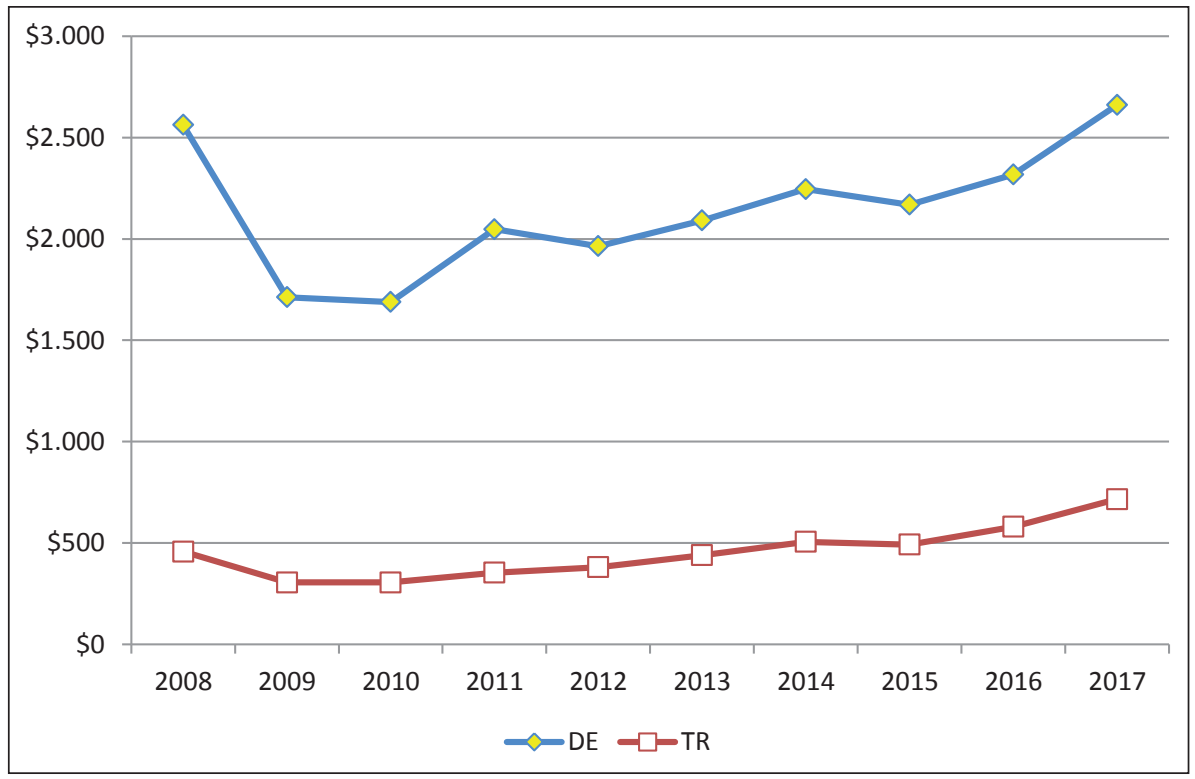

Source: TÜiK and Destatis, 2018.

In 2015, Halkbank purchased 76.76 percent of Cacanska Bank operating in Serbia and changed its name to Halkbank AD Beograd. For the first time in Serbia, Turkish capital has been active. It is predicted that this purchase would encourage new investments from Turkey to Serbia and improve commercial relations. $^{80}$ 


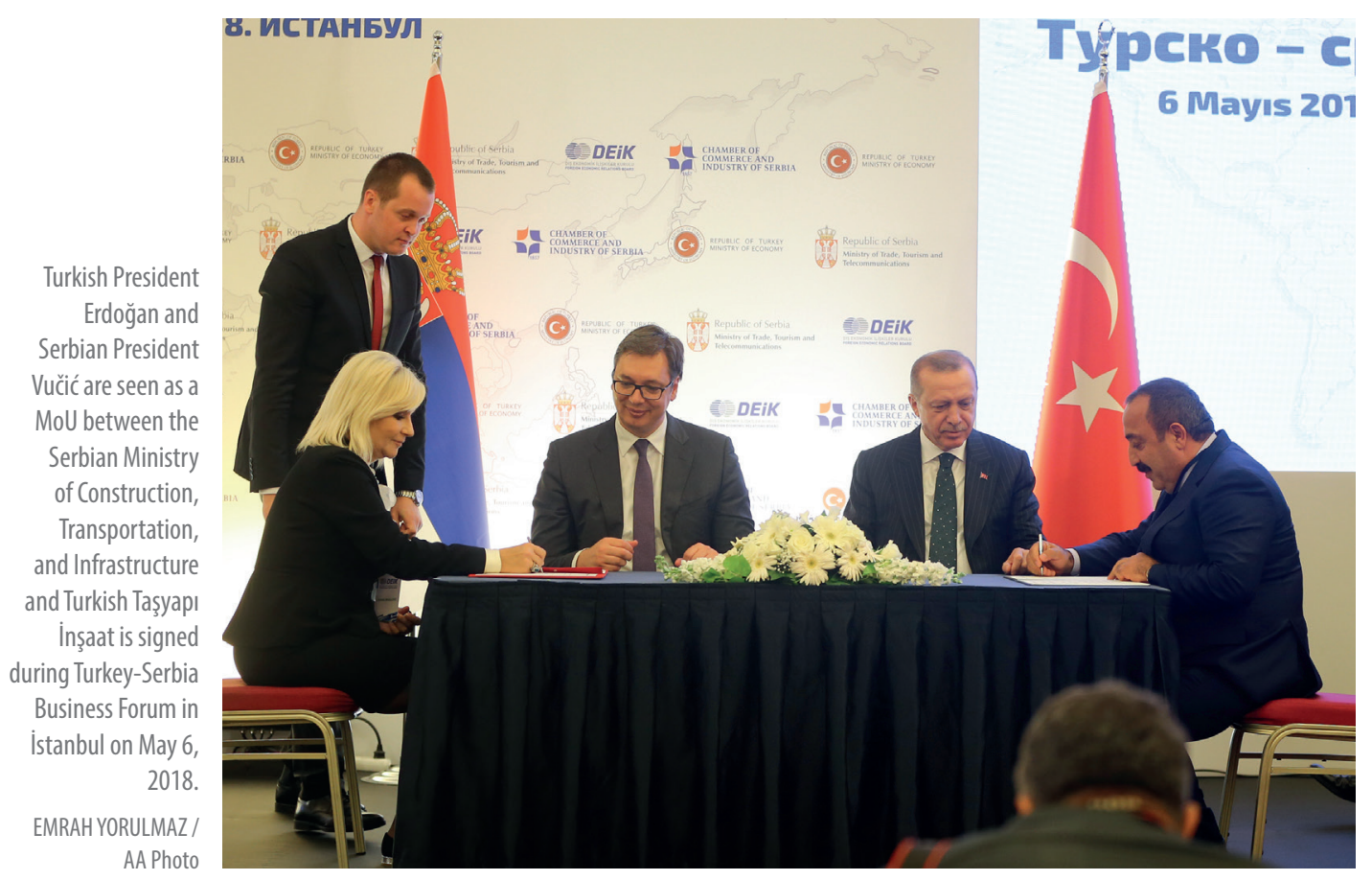

Although there is a huge attempt to improve political relations between Turkey and Serbia, due to some existing historical prejudices, bilateral cooperation cannot develop to the extent expected. However, both sides have started to behave more pragmatically over time and have increased their efforts to improve relations, which in turn have resulted in more interaction. ${ }^{81} \mathrm{~A}$ free trade agreement, which became effective in 2010 between Serbia and Turkey allows Turkish businessmen to export their goods through Serbia to about 1 billion inhabitants of third countries that have free trade agreements with Serbia such as Russia, Belarus, Kazakhstan, and the European Union. This opportunity is still to be exploited by Turkish businessmen. ${ }^{82}$

When we look at the product groups exported to Serbia by Turkey and Germany, it is seen that Germany exports a huge number of electrical goods, appliances and tools, motor vehicles, power generating machines, general industrial machines, and the machinery specialized for particular industries. ${ }^{83}$ Turkey mostly exports textile products, motor vehicles, clothing, electrical goods, fruits and vegetables to Serbia. ${ }^{84}$ Electrical goods rank the third on Turkey's exports list, but they are in lower volumes compared to Germany. Turkey's exports of apparel and clothing accessories increased by 52 percent, electrical goods by 23 percent, motor vehicles and parts by 22 percent, and textile products by 14 percent from 2016 to 2017 . Turkish exporters who are interested in being competitive in Serbian markets should spend more effort on higher tech- 
nology level products so that Turkey might have an opportunity to compete in the Serbian market with Germany.

\section{Greece}

The Greek-German cooperation which was started in the 1900s in the fields of law and medicine in academia is still influential. As a consequence, the number of German-speaking lawyers, doctors and academicians in Greece is quite high. There is an intense traffic in the academia between Germany and Greece. To date, more than 2,500 Greek students have earned their master's and doctorate degrees in Germany with the German Academic Exchange Service (DAAD) scholarship, and more than 300 Humboldt Research Scholarships have been awarded. In the period 2015-2016 there were about 7,000 Greek students studying in Germany, out-with the Erasmus program. ${ }^{85}$

Most of the foreign direct investments in Greece are made by the EU countries. Although there are significant changes in ranking of the countries that have invested directly in Greece before and after the crisis, Germany ranks the first in both periods. Deutsche Telekom has a 40 percent share of the OTE, the Greek telecommunications group. German companies have been active in the country for years. Major infrastructure projects in Greece like Athens Underground and Athens Airport were carried out by German companies. Foreign direct investments in Greece decreased by 38.7 percent in the six-year period after the 2008 crisis compared to the previous six-year period. ${ }^{86}$ Germany's investments to Greece also swiftly dropped down in the 2008 crisis and European debt crisis in 2010.

In 2017, the biggest export partners of Greece were Italy, Germany, South Cyprus, and Turkey. On the other hand, the biggest three import partners of Greece were Germany, Italy, and Russia, while Turkey ranks $12^{\text {th }}$ in Greece's imports. There are only 20 Turkish-funded companies and businesses registered in Athens Commercial Counseling. When we compare this number with Romania and Bulgaria that are also in the same geographical region, a very low number of Turkish-affiliated companies in Greece is quite remarkable. Since 1995, the Schengen system has restricted the ability of Turkish citizens to freely travel to Greece, and disrupted the activities of businessmen, exporters, students, and tourists. ${ }^{87}$

The sluggish economic relations between Turkey and Greece have many reasons. During the 1990s, Turkey had its own economic difficulties and the po- 
litical turmoil between the two countries continued. Turkish-Greek trade relations expanded dramatically in the 2000-2008 periods due to the expansion of the world economy and the Europeanization of Greece and Turkey relations, accompanied by domestic political economy transformations. Bilateral trade volume passed $\$ 1$ billion for the first time in history ( $\$ 1.34$ billion) in 2003 and reached $\$ 3.58$ billion at the end of 2008 . Increase in trade volumes created functional spillover effects and paved the way for the development in foreign direct investment. The number of Greek companies established in Turkey increased from 76 in 2003 to 346 in 2008 and ranked Greece as the third biggest source of FDI in Turkey, whereas there were not many Turkish companies that invested in Greece. ${ }^{88}$ In 2010, trade transactions between Greece and Turkey reached the volume of $\$ 5$ billion and they increased further to $\$ 6.5$ billion in $2012 .{ }^{89}$

Greece's immediate and direct connection to the coasts of Turkey makes a significant contribution to the number of tourists bilaterally, which is also facilitated by a simplified visa regime for travel to the Greek islands. In addition, within the scope of the Turkish Students Scholarships, many students from Greece study at higher education institutions in Turkey. ${ }^{90}$

Figure 5: Exports of Germany and Turkey to Greece between 2008-2017 (Million \$)

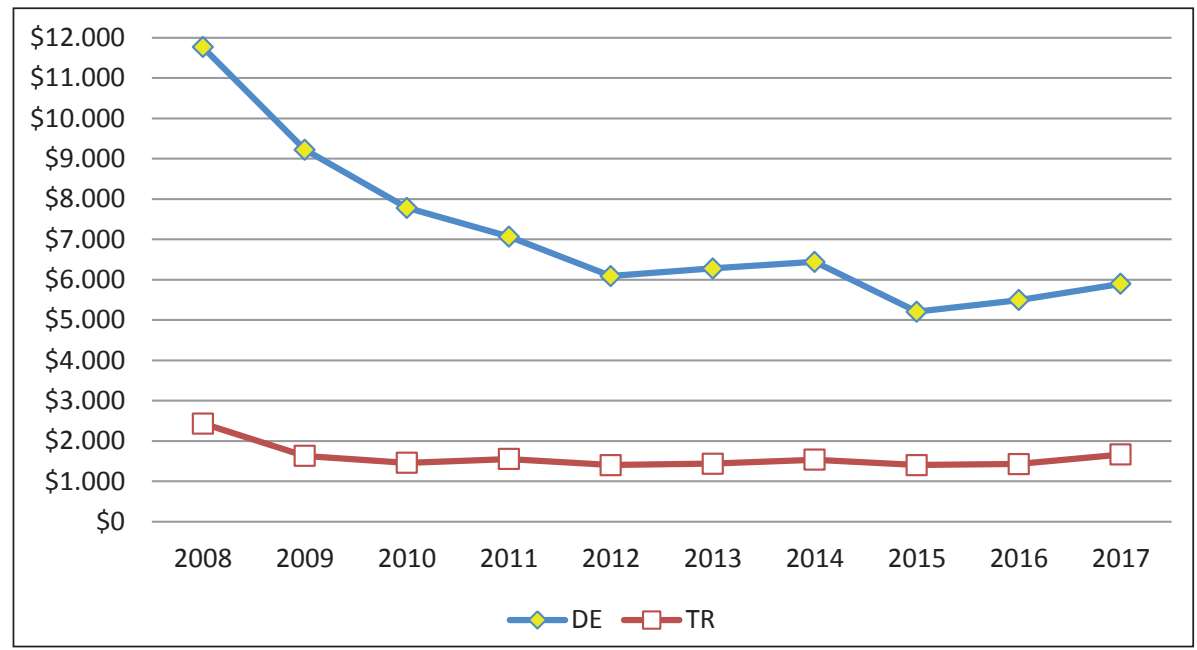

Source: TÜiK and Destatis, 2018.

When we compare Turkey and Germany's exports to Greece, it can be seen that Germany exports more medical and pharmaceutical products to Greece unlike other Balkan countries. In addition, milk, dairy products, and eggs are among the top five products exported to Greece from Germany in the 2008-2017 period, while meat and meat products are among the top ten exported products. In 2017, Germany exported \$264 million worth of milk, dairy products, and eggs; and \$182 million worth of meat and meat products. Motor vehicles, in- 
dustrial machines, and electric machines are other product groups within the top five exported goods. ${ }^{91}$

Turkey mostly exports to Greece textile products worth of $\$ 155$ million, iron and steel, natural gas, motor vehicles, oil products derived from oil, and electrical goods. ${ }^{92}$ Although Turkey's export volumes are not as high as Germany, Turkey has an opportunity to compete with Germany in Greek markets in motor vehicles and their parts, and electrical goods. Turkey's exports in motor vehicles and parts have increased by 28 percent in the last year. Due to inadequate industrial infrastructure in Greece, both countries have low amounts of exports in the industrial machinery sector.

\section{Specific strategies to increase trade volumes to each Balkan country are needed to be developed by Turkey's Ministry of Commerce and Turkish Exporters Assembly}

\section{Conclusion and Policy Suggestions}

According to our findings, the commercial competition between Turkey and Germany in the Balkans is currently not serious. Turkey is strong in the exports of textile products, and raw materials like iron and steel. However, if the export tendency of Turkey continues in the same direction, and Turkey succeeds in realizing Industry 4.0 plans and fosters high-tech machinery production as mentioned in the recently announced Digital Turkey Road Map, ${ }^{93}$ the country might compete with Germany in some fields in the Balkan markets in the medium and long run. Areas that are likely to compete are electrical goods and appliances, motor vehicles, bicycles and motorcycles, parts and components, power generating machinery and vehicles, metal articles, textile products, general and specific industrial machines, and plastics. Turkey's export volumes of these products to the Balkan countries have increased substantially during our examination period. Hence, it is expected that with the digital transformation of Turkey, it will make a breakthrough in these sectors and be more competitive in international markets as well as in the Balkan countries using the political achievement it has already attained in the last two decades. Moreover, the suspension of the EU accession process of some Balkan countries leads them to search for alternative investors. Turkey should take advantage of this conjuncture in the region and strengthen its position in economic and financial terms.

Turkey's governmental and NGO activities in the Balkans have increased remarkably since 2002. Turkey's cultural and historical ties to the Balkan countries are expressed in a variety of political and business meetings, but these are not materialized in the form of increased investment and commercial relations. However, this does not mean that Turkey's efforts to improve political, cultural, 
and economic relations with the Balkan countries have failed, but that Turkey needs to revise its Balkans strategy to make better use of its close relations with the countries in the region and transform them into higher trade volumes and foreign direct investments. European authorities have already expressed that Turkey and its role in the Balkans do not compete with the European goals but rather complement them. Hence, in this favorable environment, Turkey needs to deepen its trade and investment relations with the region. So far, in the last two decades, we have witnessed Turkey's improved cultural and political relations with all countries in the Balkans, even with the ones with which it has deep-rooted historical problems. Unfortunately, business and economic relations have not followed this achievement. If Turkey is to attain its 2023 goals of $\$ 500$ million of exports, it has to export more to the Balkan states which are geographically, historically and culturally very close to Turkey.

It should be admitted that trade and investment decisions are rational decisions of economic actors. They are not centrally planned and governed by the states. Despite this, the Turkish government, especially the Ministry of Trade, should study the Balkan countries one by one and develop strategies to enter into these markets accordingly. If favorable conditions are prepared for Turkish businessmen, they are going to follow the path which promises high profits and large markets. According to our findings, we suggest that a general Balkans strategy does not help Turkish tradesman and investors. Each country in the Balkans has its own characteristics and own way of doing business. Moreover, most exported product groups differ also according to the destination. Therefore, specific strategies to increase trade volumes to each Balkan country are needed to be developed by Turkey's Ministry of Commerce and Turkish Exporters Assembly.

\section{Endnotes}

1. Jasmin Ademovic, "Great Power Competition in the Balkans Heating Up," Geopolitical Monitor, (November 7, 2016), retrieved June 10, 2017, from https://www.geopoliticalmonitor.com/great-power-competition-in-the-balkans-heating-up/; Alida Vračić, "Turkey's Role in the Western Balkans," Stiftung Wissenschaft und Politik -SWP- Deutsches Institut für Internationale Politik und Sicherheit, (December 2016), retrieved from http://nbn-resolving.de/urn:nbn:de:0168- ssoar-50173-5; Dušan Spasojević, "The Turkish-German Balkan Equation," LSEE Research on South Eastern Europe, (July 17, 2014), retrieved from http://blogs.Ise.ac.uk/lsee/2014/07/17/the-turkish-german-balkan-equation/.

2. Paul J. Welfens, Stabilizing and Integrating the Balkans: Economic Analysis of the Stability Pact, EU Reforms and International Organizations, (Berlin Heidelberg: Springer, 2012), p. 72.

3. Selin Çalık Muhasilovic, "Analysis: Turkey's Balkan Policy not Interest Oriented," Anadolu Agency, (January 23, 2016), retrieved from https://www.aa.com.tr/en/turkey/analysis-turkey-s-balkan-policy-not-interest-oriented/509237.

4. Nebi Miş et al. (eds.), 2015'te Türkiye, (İstanbul: SETA, 2015), retrieved May 17, 2018, from http://file. setav.org/Files/Pdf/20160107162718_2015te-turkiye.pdf.

5. İnan Rüma, "Turkish Foreign Policy Towards the Balkans: New Activism, Neo-Ottomanism or/so What?" Turkish Policy Quarterly, Vol. 9, No. 4 (2010), pp. 133-140; Bülent Aras, "Turkey and the Balkans: 
New Policy in a Changing Regional Environment," GMF Analysis on Turkey, (October 31, 2012), retrieved from http://www.gmfus.org/publications/turkey-and-balkans-new-policy-changing-regional-environment, p. 3.

6. Interview with Ahmet Davutoğlu, "The Business World Is the Pioneers of the Foreign Policy" Turkishtime, (April-May 2004).

7. Kemal Kirişçi, "The Transformation of Turkish Foreign Policy: The Rise of the Trading State," New Perspectives of Turkey, No. 40 (2009), pp. 29-57, retrieved April 04, 2018, from https://pdfs.semanticscholar. org/d658/67de5df577a9e392d91cd4927e76f04e158c.pdf.

8. Dimitar Bechev, "Turkey in the Balkans: Taking a Broader View," Insight Turkey, Vol. 14, No. 1 (2012), pp. 131-146.

9. Vračić, "Turkey's Role in the Western Balkans."

10. Ivana Sekularac, "Spurned by EU Investors, Balkans Looks to Eager Turkey," Reuters Business News, (May 18, 2018), retrieved from https://www.reuters.com/article/us-balkans-turkey/spurned-by-eu-investors-balkans-looks-to-eager-turkey-idUSKCN1IJ20Y.

11. Matteo Bonomi and Dušan Reljić, "The EU and the Western Balkans: So Near and Yet So Far," German Institute for International and Security Affairs SWP, (December 2017); Dušan Reljić, "Does the EU Want to Bring Russia and Turkey into the Western Balkans?" Euractiv, (2014), retrieved June 12, 2018, from https://www.euractiv.com/section/global-europe/opinion/does-the-eu-want-to-bring-russia-and-turkey-into-the-western-balkans/.

12. Jovana Gec and Dusan Stojanovic, "Turkey's Crisis could Slow Its Push for Influence in Balkans," Financial Post, (September 4, 2018), retrieved from https://business.financialpost.com/pmn/business-pmn/ turkeys-crisis-could-slow-its-push-for-influence-in-balkans.

13. Faisal al-Yafai, "Turkey's Growing Influence in the Balkans Has Profound Implications for the Middle East," The National, (June 5, 2018), retrieved June 5 2018, from https://www.thenational.ae/opinion/comment/turkey-s-growing-influence-in-the-balkans-has-profound-implications-for-the-middleeast-1.737313.

14. Emre Hatipoğlu, "Turkey - EU Cooperation in Foreign Policy: Some Thoughts," in Ebru Turhan and Günter Seufert (eds.), German Interests and Turkey's EU Accession Process: A Holistic Perspective, (İstanbul: İstanbul Policy Center, 2015), pp. 13-14.

15. Marija Mitrovic, "Turkish Foreign Policy towards the Balkans: The Influence of Traditional Determinants on Davutoğlu's Conception of Turkey-Balkan Relations," GeT MA Working Paper Series, No. 10 (2014), retrieved from https://edoc.hu-berlin.de/bitstream/handle/18452/3742/10.pdf?sequence=1.

16. Elif Nuroğlu and Hüseyin H. Nuroğlu, Turkey and Germany in the Balkans: Export Flows and Foreign Direct Investments, (istanbul: SETA Publications, 2016), retrieved from https://www.setav.org/balkanlarda-almanya-ve-turkiye-ihracat-ve-yatirimlar/; Phillipe Perchoc, "Turkey's Influence in the Western Balkans," European Parliamentary Research Service (EPRS), (July 6, 2017), retrieved from http://www.europarl. europa.eu/RegData/etudes/ATAG/2017/607300/EPRS_ATA(2017)607300_EN.pdf.

17. Žarko Petrović and Dušan Reljić, "Turkish Interests and Involvement in the Western Balkans: A ScoreCard," Insight Turkey, Vol 13, No. 3 (2011), pp. 159-172.

18. Miş et al. (eds.), 2015'te Türkiye.

19. Nebi Miş et al. (eds.), 2017'de Türkiye, (İstanbul: SETA, 2017), retrieved August 15, 2018, from https:// setav.org/assets/uploads/2018/01/2017de_turkiye.pdf.

20. Erhan Türbedar, "Turkey in the Balkans: Myths, Illusions and Realities," Deutsche Welle, (May 16, 2012), retrieved April 10, 2018, from http://www.dw.com/en/turkey-in-the-balkans-myths-illusions-and-realities/a-15953307.

21. Dušan Spasojević, "The Turkish-German Balkan Equation."

22. Sekularac, "Spurned by EU investors, Balkans Looks to Eager Turkey."

23. Lars Hänsel and Florian C. Feyerabend, "The Influence of External Actors in the Western Balkans," Konrad-Adenauer-Stiftung, (September 12, 2018), retrieved from https://www.kas.de/web/rlpsee/publikationen/einzeltitel/-/content/der-einfluss-externer-akteure-auf-dem-westbalkan-v7. 
24. Eleonora Cutrini and Francesca Spigarelli, "The Role of FDI in Southeast Europe's International Integration: A Focus on Investors from the Marche Region," Journal of Comparative Economics, Vol. 9, No. 3 (2012), pp. 395-424.

25. Marko Djuric, "Reasons for Nearshoring to Eastern Europe," Interventure, (July 5, 2016), retrieved August 15, 2018, from https://www.interventure.info/blog/reasons-for-nearshoring-to-eastern-europe/; Thomas Meyer, "Offshoring to New Shores: Nearshoring in Central and Eastern Europe," Deutsche Bank Research, (August, 2006), retrieved August 15, 2018, from https://mpra.ub.uni-muenchen.de/5785/.

26. Claudia Ehrenstein, "Deutschland hat vier Milliarden in den Balkan Gesteckt," Die Welt, (August 12, 2015), retrieved August 10, 2018, from https://www.welt.de/politik/deutschland/article145144480/ Deutschland-hat-vier-Milliarden-in-den-Balkan-gesteckt.html.

27. Hänsel and Feyerabend, "The Influence of External Actors in the Western Balkans."

28. Erhan Türbedar, "How the Turkish Foreign Policy Is Perceived in the Balkans?" TEPAV Economic Policy Research Foundation of Turkey Evaluation Note, (April 2012), retrieved July 18, 2018, from https://www. tepav.org.tr/upload/files/haber/1252593163r2568.Economic_Policy_Research_Foundation_of_Turkey. pdf.

29. Miglena S. Todorova, "Foreign Investment Inflows to Former Socialist Countries in the Balkans: Mapping Global Capitalism," Interventions, Vol. 20, No. 6 (2018).

30. Loic Poulain and Akis Sakellariou, "Western Balkans: Is Turkey back?" Center for Strategic \& International Studies, (April 25, 2011), retrieved April 7, 2016, from http://csis.org/blog/western-balkans-turkey-back.

31. Perchoc, "Turkey's Influence in the Western Balkans."

32. Kemal İnat, "Economic Relations between Turkey and Germany," Insight Turkey, Vol. 18, No. 1 (Winter 2016), pp. 21-35.

33. Perchoc, "Turkey's Influence in the Western Balkans."

34. Birgül Demirtaş, “Turkey and the Balkans: Overcoming Prejudices, Building Bridges and Constructing a Common Future," Perceptions, Vol. 18, No. 2 (Summer 2013), pp. 163-184, retrieved September 05, 2018, from http://sam.gov.tr/tr/wp-content/uploads/2013/09/Birgul_Demirtas.pdf; Kemal Karpat, "Balkans from Past to Present," Çerçeve, Vol. 21, pp. 36-40, retrieved September 05, 2018, from http://www.musiad. org.tr/F/Root/burcu2014/Ara\%C5\%9Ft\%C4\%B1rmalar\%20Yay\%C4\%B1n/Pdf/\%C3\%87er\%C3\%A7eve/ Cerceve_Dergisi_Sayi_62.pdf.

35. Zia Weise, "Turkey's Balkan Comeback," Politico, (May 17, 2018), retrieved June 15, 2018, from https:// www.politico.eu/article/turkey-western-balkans-comeback-european-union-recep-tayyip-erdogan/.

36. Turkish Statistical Institute, retrieved June 01, 2018, from https://biruni.tuik.gov.tr/disticaretapp/disticaret.zul? param $1=3 \&$ param $2=4 \&$ sitcrev $=3 \&$ isicrev $=0 \&$ sayac $=5806$.

37. Federal Statistical Office of Germany, retrieved June 02, 2018, from https://www-genesis.destatis.de/ genesis/online/data;sid=2AA0DA4C8101703B11F16616E21F5D23.GO_1_5?operation=abruftabelleAbrufen\&selectionname=51000-0007\&levelindex=1\&levelid=1556263522595\&index=7.

38. "Bulgarien: Beziehungen zu Deutschland," Auswärtiges Amt, retrieved June 10, 2018, from https:// www.auswaertiges-amt.de/de/aussenpolitik/laender/bulgarien-node/bilateral/210156.

39. Datenblatt Bulgarien, Botschaft der Bundesrepublik Deutschland Sofia, (March 2015).

40. "Bulgarien: Beziehungen zu Deutschland."

41. Datenblatt Bulgarien, Botschaft der Bundesrepublik Deutschland Sofia, (February 2018).

42. "Bulgarien: Beziehungen zu Deutschland."

43. Todorova, "Foreign Investment Inflows to Former Socialist Countries in the Balkans."

44. "Bulgaristan - Genel Ekonomik Durum," T.C. Ministry of Trade, retrieved August 10, 2018, from https:// ticaret.gov.tr/yurtdisi-teskilati/avrupa/bulgaristan/ulke-profili/ekonomik-gorunum/genel-ekonomikdurum.

45. Turkish Statistical Institute. 
46. Federal Statistical Office of Germany.

47. Turkish Statistical Institute.

48. “Deutsche Firmen Drängen ins Kosovo," Die Welt, (July 14, 1999) , retrieved April 3, 2018, from https:// www.welt.de/print-welt/article577106/Deutsche-Firmen-draengen-ins-Kosovo.html.

49. Claudia Ehrenstein, "Deutschland hat vier Milliarden in den Balkan Gesteckt."

50. Auswärtiges Amt, retrieved June 03, 2018, from https://www.auswaertiges-amt.de/de/aussenpolitik/ laender/kosovo-node/-/207464.

51. "Kosova - Genel Ekonomik Durum," T.C. Ministry of Trade, retrieved July 28, 2018, from https://ticaret. gov.tr/yurtdisi-teskilati/avrupa/kosova/ulke-profili/ekonomik-gorunum/genel-ekonomik-durum.

52. "Doğrudan Yabancı Yatırımlar," T.C. Ministry of Trade, (August 31, 2018), retrieved September 05, 2018, from https://ticaret.gov.tr/yurtdisi-teskilati/avrupa/kosova/ulke-profili/ekonomik-gorunum/dogrudanyabanci-yatirimlar.

53. "Limak'ın 140 Milyon Euroluk Yatırımı Kosova'yı Uçuracak," Akşam, (October 24, 2013), retrieved May 29, 2016, from http://www.limak.com.tr/basin-odasi/basinda-limak/2013/limakin-140-milyon-euroluk-yatirimi-kosovayi-ucuracak.

54. "Türk-Kosova İş Forumu," Dış Ekonomik Iliş̧kiler Kurulu, retrieved May 29, 2016, from https://www. deik.org.tr/Konseylcerik/1788/T\%C3\%BCrk_Kosova_\%C4\%B0\%C5\%9F_Forumu.html.

55. "Türkiye ile Ticaret," T.C. Ministry of Trade, retrieved August 03, 2018, from https://ticaret.gov.tr/yurtdisi-teskilati/avrupa/kosova/ulke-profili/ekonomik-gorunum/turkiye-ile-ticaret.

56. "Türk-Kosova İş Forumu," Dış Ekonomik iliş̧kiler Kurulu.

57. Ahmet Mithat Milli, "Kosova Yatırım için Cazip bir Ülke," Kosova Haber, (June 3, 2011), retrieved May 28, 2016, from http://www.kosovahaber.net/?page=2,21,6890.

58. Turkish Statistical Institute; Federal Statistical Office of Germany.

59. "Dış Ticaret Politikası ve Vergiler," T.C. Ministry of Trade, retrieved August 13, 2018, from https://ticaret. gov.tr/yurtdisi-teskilati/avrupa/romanya/ulke-profili/ekonomik-gorunum/dis-ticaret-politikasi-ve-vergiler.

60. "Why Romania Needs to Be on Your Outsourcing (BPO) List," (July 8, 2015), Telus International, retrieved May 05, 2018, from https://web.telusinternational.com/articles/why-romania-needs-to-be-onyour-bpo-list/.

61. "Genel Ekonomik Durum," T.C. Ministry of Trade, retrieved August 13, 2018, from https://ticaret.gov.tr/ yurtdisi-teskilati/avrupa/romanya/ulke-profili/ekonomik-gorunum/genel-ekonomik-durum.

62. "Relations with Romania," T.C. Ministry of Foreign Affairs, retrieved June 03, 2018, from http://www. mfa.gov.tr/relations-between-turkey-and-romania.en.mfa.

63. Kadife Şahin, "Ziraat in the Bank Number, Özyeğin in the Size Ahead," Milliyet, retrieved June 05, 2016, from http://www.milliyet.com.tr/Ekonomi/HaberDetay.aspx?aType=HaberDetayArsiv\&KategoriID=3\&ArticleID=975606.

64. "Yurtdışında Bankacılık Atağı," Dünya Gazetesi, (January 24, 2012), retrieved June 05, 2016, from http://www.dunya.com/guncel/yurtdisinda-bankacilik-atagi-144132h.htm.

65. "Rumänien: Beziehungen zu Deutschland," Auswärtiges Amt, retrieved June 02, 2018, from https:// www.auswaertiges-amt.de/de/aussenpolitik/laender/rumaenien-node/bilateral/210204\#content_1.

66. "Romanya'ya 'Alman' Cumhurbaşkanı," Haberturk, (November 17, 2014), retrieved August 14, 2016, from http://www.haberturk.com/dunya/haber/1010221-romanyaya-alman-cumhurbaskani.

67. "Rumänien: Beziehungen zu Deutschland."

68. Federal Statistical Office of Germany.

69. Turkish Statistical Institute.

70. "Sırbistan - Genel Bilgiler," T.C. Ministry of Trade, retrieved August 03, 2018, from https://ticaret.gov.tr/ yurtdisi-teskilati/avrupa/s\%C4\%B1rbistan/ulke-profili/genel-bilgiler. 
71. "Sırbistan - Türkiye ile Ticaret," T.C. Ministry of Trade, retrieved August 03, 2018, from https://ticaret. gov.tr/yurtdisi-teskilati/avrupa/s\%C4\%B1rbistan/ulke-profili/turkiye-ile-ticaret.

72. "Sırbistan - Dış Ticaret," T.C. Ministry of Trade, retrieved August 03, 2018, from https://ticaret.gov.tr/ yurtdisi-teskilati/avrupa/s\%C4\%B1rbistan/ulke-profili/dis-ticaret.

73. "Serbien: Beziehungen zu Deutschland," Auswärtiges Amt, retrieved June 02, 2018, from https:// www.auswaertiges-amt.de/de/aussenpolitik/laender/serbien-node/bilateral/207492.

74. "Sırbistan'da Türk Yatırımları," Turizm Habercisi, (April 21, 2011), retrieved June 08, 2016, from http:// www.turizmhabercisi.com/sirbistanda-turk-yatirimlari.html.

75. Suha Umar, "No Visa No Tax: 7 Countries You Can Work," Patronlar Dünyası, (September 29, 2010), retrieved June 08, 2016, from http://www.patronlardunyasi.com/.

76. "Serbien: Beziehungen zu Deutschland."

77. Claudia Ehrenstein, "Deutschland hat vier Milliarden in den Balkan Gesteckt."

78. "Serbien: Beziehungen zu Deutschland."

79. "Sırbistan - Türkiye ile Ticaret."

80. Miş et al. (eds.), 2015'te Türkiye.

81. Vračić, "Turkey's Role in the Western Balkans."

82. Erhan Türbedar, "Türkiye-Sırbistan İlişkilerinin Ekonomik Boyutu," TurkishNy, (March 16, 2012), retrieved April 14, 2016, from http://www.turkishny.com/dr-erhan-turbedar/108-dr-erhan-turbedar/83530-turkiye-sirbistan-iliskilerinin-ekonomik-boyutu\#.VrNXb7KLTZ4.

83. "Serbien: Wirtschaft," Auswärtiges Amt, retrieved May 02, 2018, from https://www.auswaertiges-amt. de/de/aussenpolitik/laender/serbien-node/wirtschaft/207504.

84. "Sırbistan - Türkiye ile Ticaret."

85. "Serbien: Beziehungen zu Deutschland."

86. "Serbien: Wirtschaft."

87. Bahar Rumelili, "The European Union and Cultural Change in Greek-Turkish Relations," Working Papers Series in EU Border Conflicts Studies, No. 17.

88. Mustafa Kutlay, "A Political Economy Approach to the Expansion of Turkish-Greek Relations: Interdependence or Not?" Perceptions, (Spring-Summer 2009), pp. 91-121.

89. George Koukoudakis, "Explaining the Endurance of Greek-Turkish Rapprochement Process," Uluslararası Illişkiler, Vol. 11, No. 44 (2015), pp. 81-100.

90. "Türkiye-Yunanistan İlişkileri," T.C. Ministry of Foreign Affairs, retrieved June 11, 2016, from http:// www.mfa.gov.tr/turkiye-yunanistan-siyasi-iliskileri.tr.mfa.

91. Federal Statistical Office of Germany.

92. Turkish Statistical Institute.

93. "Turkey's Industrial Revolution Digital Turkey Road Map," T.C. Ministry of Science, Industry and Technology, retrieved August 04, 2018, from https://www.sanayi.gov.tr/tsddtyh.pdf. 